\title{
Assessment of Chemical Disinfectants Efficacy against Escherichia coli Biofilm Developed on Glass and Wood at Refrigeration and Room Temperatures
}

\author{
Anas Muazu ${ }^{1 *}$, Nor Iza A. Rahman ${ }^{1}$, Umar Faruk Abdullahi $^{2}$, Sani Aliyu ${ }^{2}$, Jonathan Ajisafe Ogidi ${ }^{3}$, Ahmed Faruk Umar ${ }^{4}$ \\ ${ }^{1,2}$ Faculty of Medicine, Universiti Sultan Zainal Abidin, Kampus Perubatan, Jalan Sultan Mahmud, 20400 Kuala Terengganu, Malaysia. \\ ${ }^{3}$ Department of Biomathematics, National Mathematical Center Abuja, Nigeria P. M. B. 118, Abuja, Nigeria. \\ ${ }^{4}$ Department of Biological Sciences, AbubakarTafawa Balewa University Bauchi, Nigeria.
}

\begin{tabular}{l} 
ARTICLE INFO \\
\hline Article history: \\
Received on: 04/10/2015 \\
Revised on: 07/11/2015 \\
Accepted on: $26 / 11 / 2015$ \\
Available online: $27 / 12 / 2015$ \\
\hline Key words: \\
Biofilm, E. coli, Log \\
Reduction, Survival \\
Fractions.
\end{tabular}

\begin{abstract}
Objectives: The aim of this work was to study the formation of biofilm on glass and wood coupons at refrigeration and room temperatures, different incubation periods and to assess the efficacy of hydrogen peroxide (HP), Para Acetic Acid (PAA), Sodium hypochlorite (SH) and mixture of PAA + SH against the biofilm. Method: $200 \mu \mathrm{L}$ of $10^{8}$ suspension E. coli ATCC 29922 was inoculated on the coupons inside petri dishes containing $20 \mathrm{ml}$ of tryptic soy broth, incubated at 10 and $27^{\circ} \mathrm{C}$ for $24,48,72$ and 168 hours. Biofilm developed at each hour above was quantified by bead-vortex followed by agar plating. The action of disinfectants was tested on 168 hours biofilm. The surfaces were exposed to the disinfectants and incubated at $27{ }^{\circ} \mathrm{C}$ for 10 minutes, followed by deactivation for 5 minutes. Cells that resisted disinfectants effect were vortexed and enumerated by agar plating.

Results: The results showed that $E$. coli can develop high biofilm on wood apart from glass. After disinfection treatment, HP had the highest efficacy at $27^{\circ} \mathrm{C}$ followed by PAA then SH, whilst PAA + SH had the least.

Conclusion: It can be concluded that HP and PAA can be good disinfectants agents against $E$. coli biofilm.
\end{abstract}

\section{INTRODUCTION}

The term biofilm is used to describe matrix-enclosed bacterial population adherent to each other and/or to surfaces (Costerton et al., 1995). Biofilm production is an important mechanism for bacterial survival and its occurrence together with antimicrobial resistance represent a challenge for clinical management. Biofilm formation occurs when microorganism attached to a surface and through growth and continuing colonization, spread over the surface. Biofilm formation occurs when microorganism attached to a surface and through growth and continuing colonization, spread over the surface. Bacteria in natural environment usually form biofilm communities of sessile organisms embedded in a hydrated matrix of extracellular polymeric slime with polysaccharides, nucleic acid and proteins (Costerton et al., 1999). Inside the host, the matrix protects

\footnotetext{
* Corresponding Author
}

Email:anasinmuazu2@gmail.com, Tel; +60146456792, +2348030599619 biofilm bacteria from exposure to innate immune defenses (such as opsonization and phagocytosis) and antibiotic treatments (Jesaitis et al., 2003; Cerca et al., 2007). Escherichia coli (E. coli) are genetically diverse species that causes diarrheal diseases and variety of extra intestinal infections which fulfill many or all of the proposed criteria for biofilm-associated infections (Kaper et al., 2004). The diseases in which biofilms play a major role tend to be chronic and difficult to treat. In modern clinical microbiology, establishment of bacterial biofilm is considered a pathogenicity threat during chronic infections (Sritharan and Sritharan 2004). Biofilm in food processing environment is of special importance as it has the potential to act as the chronic source of microbial contamination that may lead to food spoilage or transmission of diseases (Stepanovic et al.,2004).The infectious dose of the pathogen is as low as 10 to 100 organisms/cells (Feng and Weagant 2002). E. coli infection is also responsible for most cases of hemolytic uremic syndrome, a major cause of acute renal failure in children (Boyce et al., 1995). Infections due to pathogenic $E$. coli may be limited to colonization of mucosal surfaces or can 
disseminate throughout the body and had been reported to have effect in urinary tract infection, sepsis or meningitis and enteric diarrheal disease (Chen and Frankel, 2006). In food industry, pathogenic bacteria have been of considerable interest in the context of food safety and have provoked the interest of many research groups (Shi and Zhu, 2009). It is also evident that the attachment of pathogenic bacteria to food contact surfaces such as plastic, stainless steel, wood and glass and the subsequent biofilm formation are undesirable since the detachment of cells from the biofilm structure can lead to the cross - contamination of food products leading to food borne diseases (Brooks and Flint, 2008).

Microorganisms usually struggle to survive when exposed to a harmful environmental stress. When bacteria are exposed to sub-lethal levels of antimicrobials or biocides, only minor cell damage is caused and the consequences may include changes in their phenotype and induction of gene expression, giving rise to a more resistant population (Araujo et al., 2011). Thus, the aim of this was to study the formation of biofilm by $E$. coli on glass and wood at refrigeration and room temperature (10 $\& 27^{\circ} \mathrm{C}$ ) and also to evaluate the efficacy of hydrogen peroxide, Para Acetic Acid, Sodium hypochlorite, and mixture of Para Acetic acid and Sodium hypochlorite against the biofilm.

\section{MATERIALS AND METHODS}

\section{Bacterial Strain and culture condition}

E. coli strain ATCC 29922 was used for the study and was grown on Tryptic Soy Agar (TSA) overnight at $37^{\circ} \mathrm{C}$ and stored at $5{ }^{0} \mathrm{C}$ for further experiment.

\section{Preparation of Test Surfaces}

Glass slides employed in this study were initially soaked in acetone for 1 hour to remove manufacturing debris, washed in detergent solution, rinsed twice with distilled water, air-dried and autoclaved together with wood coupons $(3 \mathrm{~cm} \mathrm{x} 1 \mathrm{~cm})$ at $121^{0} \mathrm{C}$ for 15 minutes prior to use (Chmielewski and Frank 2003).

\section{Preparation of inoculum}

One colony from the overnight cultures was inoculated into $50 \mathrm{ml}$ plastic tube containing $5 \mathrm{ml}$ of Tryptic Soy Broth (TSB) and was incubated at $37^{\circ} \mathrm{C}$ for 2 hours. Following 2 hours of incubation, $2 \mathrm{ml}$ of the incubated strain were inoculated into 200 $\mathrm{ml}$ of TSB in a $500 \mathrm{ml}$ conical flask incubated in an orbital shaker at $37^{\circ} \mathrm{C}$ for 16 hours (Chmielewski and Frank 2003) to allow the strain reach their exponential phase. After 16 hours of incubation, $10 \mathrm{ml}$ of the incubated cultures were centrifuged at $5000 \mathrm{x} g$ for 5 min at $10^{\circ} \mathrm{C}$, washed twice in $10 \mathrm{ml}$ of phosphate buffer saline (PBS) ( $\mathrm{pH} \mathrm{7.3).} \mathrm{The} \mathrm{cell} \mathrm{pellets} \mathrm{were} \mathrm{re-suspended} \mathrm{in} 10 \mathrm{ml}$ of TSB to an optical density of 0.5 at $600 \mathrm{~nm}\left(\mathrm{OD}_{600}\right)$ which corresponds to approximately $10^{8} \mathrm{CFU} / \mathrm{ml}$ (Merode et al., 2006).

\section{Biofilm formation in vitro}

Biofilm formation on the two coupons was conducted using the method described by Kostaki et al., (2012). $200 \mu \mathrm{l}$ of $10^{8}$ $\mathrm{CFU} / \mathrm{ml}$ suspension of $E$. coli strain was inoculated on each of the coupons inside petri-dishes and was allowed to attach for 3 hours at room temperature. Following the attachment step, $20 \mathrm{ml}$ of TSB was introduced into each of the petri-dishes containing the coupons. The surfaces were incubated at 10 and $27{ }^{\circ} \mathrm{C}$ for a period of $24,48,72$ and 168 hours to allow for biofilm development.

\section{Enumeration of biofilm cells}

The enumeration of viable biofilm cells on glasses and wood coupons was performed after 24, 48, and 72 hours using bead-vortex method described by Giaouris and Nychas (2006). Initially, the coupons were carefully removed from the petri dishes using sterile forceps, rinsed twice by pipetting with $10 \mathrm{ml}$ of PBS, with shaking in order to remove loosely attached cells. After the second rinsing step, each coupon was individually transferred into $50 \mathrm{ml}$ plastic tube containing $10 \mathrm{ml}$ physiological saline $(0.95 \% \mathrm{NaCl}, \mathrm{w} / \mathrm{v})$, vortexed for $2 \mathrm{~min}$ at maximum speed to detach biofilm cells from the coupons. Detached cells were subsequently enumerated by agar plating on TSA after ten-fold, six dilutions. Finally plates were removed after 24 hours of incubation. Developed colonies were counted taking a range of 3300. The experiment was repeated three times and viable cells were expressed as colony forming unit per mill (CFU/ml).

\section{Activities of Disinfectants against Biofilm}

The disinfectants employed in this study include hydrogen peroxide (HP) 30\% (R and M, Essex, U.K), Para Acetic Acid (PAA) 10\% (R and M, Essex, U.K), Sodium hypochlorite (SH) $10 \%$ (R and M, Essex, U.K) and Mixture of PAA and SH. After 168 hours biofilm development, the coupons were rinsed twice with $10 \mathrm{ml}$ of Phosphate buffer saline (PBS) $\mathrm{pH}$ (7.3) to remove any loosely attached bacterial cells, placed in separate petri dishes containing $20 \mathrm{ml}$ of each of the disinfectants under study, incubated at $27^{\circ} \mathrm{C}$ for 10 minutes with gentle shaking followed by deactivation with $10 \mathrm{ml}$ of TSB for 5 minutes (Cabeca et al., 2008). Positive controls treated the same way but with physiological saline. After 10 minutes, the actions of the disinfectants were deactivated by transferring the coupons into new petri dishes containing $10 \mathrm{ml}$ of TSB and allowed to act for 5 minutes (D.I.F.C.O Manual 1984). Following deactivation, the coupons were rinsed twice again with $10 \mathrm{ml}$ PBS, placed in plastic tubes containing $10 \mathrm{ml}$ of sterile physiological saline and 2 sterile beads, vortexed for 2 minutes (Giaouris and Nychas 2006) in order to releases viable cells adhering to the coupons into the physiological saline. The control coupons were treated equally as the test control but with Physiological saline. To count viable cells, bacteria were enumerated by agar plating after ten-fold dilutions and incubated on Tryptic Soy Agar (TSA) at $37^{\circ} \mathrm{C}$ for 24 hours. Developed colonies were counted and converted into colony forming unit/ml (CFU/ml).

The efficacy of the various disinfectants was evaluated by the ratio of untreated to the ratio of treated viable cell $\mathrm{x} 100$ which gives the survival fractions $(\mathrm{SF})$, the percentage killed (PK) was evaluated using the formula: $\mathrm{PK}=(1-\mathrm{SF}) \times 100 \%$ while the $\log$ reduction (LR) factor was evaluated using the formula: 
$\mathrm{LR}=\log _{10}(1 / \mathrm{SF}) \ldots \ldots \ldots \ldots \ldots \ldots \ldots($ Hamilton, 2011).

\section{RESULTS AND DISCUSSION}

\section{Biofilm Formation Assay at Refrigeration Temperature $\left(10^{\circ} \mathrm{C}\right)$}

E. coli an important Gram-negative anaerobic bacterium which commonly contaminates food contact surfaces in food industries can develop biofilm on medically associated devices such as catheter and mechanical heart valves. It was found from $\mathrm{m}$ this work that biofilm developed on glass coupons varied with that developed on wood coupons. At refrigeration temperature enumeration of $E$. coli viable cells after 24 hours presented a count of $2.90 \times 10^{8} \mathrm{CFU} / \mathrm{ml}$ on glass while a count of $1.80 \times 10^{8} \mathrm{CFU} / \mathrm{ml}$ was obtained on wood which was less than the count obtained on glass (Figure 1).

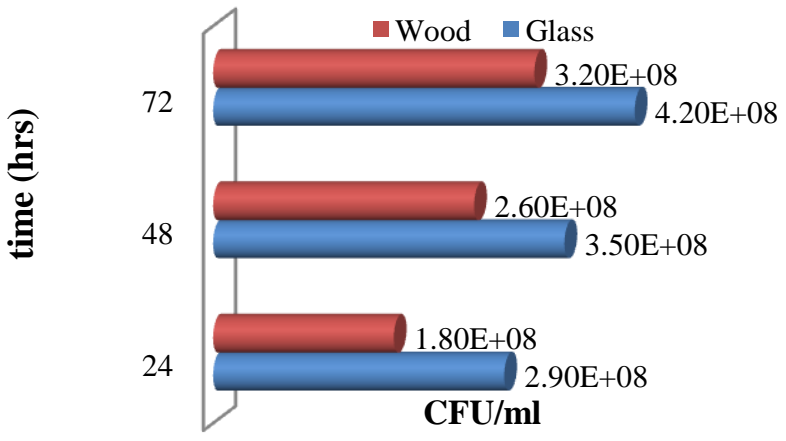

Fig. 1: Enumeration of E. coli Biofilm cells at Refrigeration Temperature $\left(10^{\circ} \mathrm{C}\right)$.

At 48 hours, the increase in incubation time has led to increase in number of biofilm cells developed on each of the surfaces. Enumeration of $E$. coli biofilm cells presented a count of $3.50 \times 10^{8} \mathrm{CFU} / \mathrm{ml}$ on glass which was relatively higher than 2.30 $\mathrm{x} 10^{8} \mathrm{CFU} / \mathrm{ml}$ quantified on wood. Variation in biofilm density on the surfaces is mainly due to their hydrophobic nature. Fletcher and Leob (1979) noted that large number of bacteria attached to hydrophobic surfaces with little or no surfaces charge while moderate number attached to hydrophobic metals with positive or neutral charge and very few attached to hydrophilic negatively charged substrate. The increase in biofilm formation with increased incubation time in this study was in line with the work of Silagyi (2007) who reported increase in biofilm development by $E$. coli on glass steel from 6, 12 and 24 hours.

At 72 hours, biofilm development on the two surfaces was higher than the previous hours of incubation with resultant bacterial count of $4.20 \times 10^{8} \mathrm{CFU} / \mathrm{ml}$ and $3.20 \times 10^{8} \mathrm{CFU} / \mathrm{ml}$ on glass and wood respectively (Figure 1). The high biofilm formation by $E$. coli on glass in this work varied with the work of Adetunji and Odetokun (2012) who reported less biofilm formationon glass and higher biofilm formation on cement coupons by $E$. coli. The increase in biofilm formation with increase incubation time obtained in this work is similar to the result reported by Mahdavi et al., (2008) who found that biofilm formed by Salmonella enteritidis on glass increased significantly from 2 to 20hours of incubation. However we are unable to find related biofilm published work on wood by $E$. coli to make comparison. Mature biofilm occur from 72 to 144 hours after initial adhesion, and may reach 240 hours (Heydon et al., 2000). Biofilm maturity occurs through population density increase, pronounced production and deposition of extracellular polymers, as well as increasing biofilm thickness (Cheng et al., 2007; Oliveira et al., 2010).

\section{Biofilm Formation Assay at Room Temperature $\left(27^{\circ} \mathrm{C}\right)$}

Enumeration of biofilm developed on the two surfaces by E. coli at room temperature showed that biofilm formation by the organism was more favored at room than at refrigeration temperature. After 24 hours enumeration biofilm formed by $E$. coli on glass yielded a count of $6.80 \mathrm{x} 108 \mathrm{CFU} / \mathrm{ml}$ on glass and $3.90 \mathrm{x}$ $108 \mathrm{CFU} / \mathrm{ml}$ on wood (Figure 2). The ability of E. coli to form biofilm on these surfaces at room temperature is a great challenge to food industries, hospital and house hold settings. This is because the increase use of wood in animal slaughter houses, chopping boards at home can provides adhesion sites for $E$. coli leading to biofilm formation and resultant outbreak of food borne diseases as well as other bacterial infections. One of the great biofilm formation issues in the food industry or other areas is cell detachment, which makes it a constant source of microorganism contamination in food, water, or new infection processes (Oliveira et al., 2010).

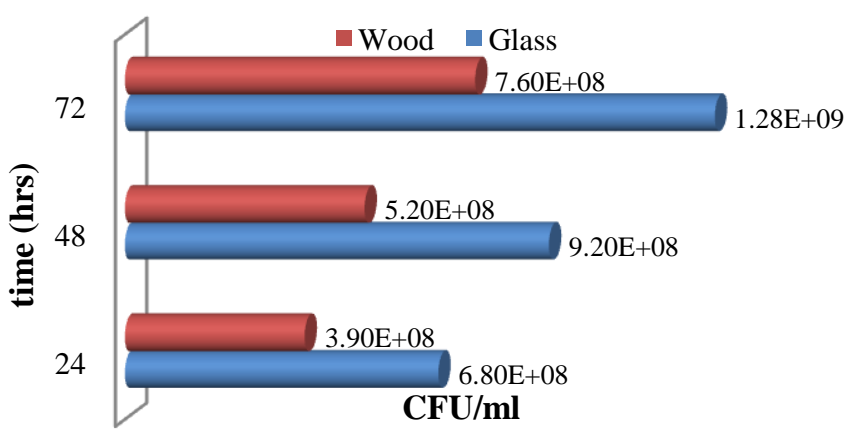

Fig. 2: Enumeration of E. coli Biofilm cells at Room Temperature $\left(27^{0} \mathrm{C}\right)$.

As observed after 48 hours of incubation, biofilm development on the surfaces also increases with increased incubation time. Following enumeration of $E$. coli viable cells, a count of $9.20 \times 10^{8} \mathrm{CFU} / \mathrm{ml}$ was obtained on glass while less biofilm with a count of $5.20 \times 10^{8} \mathrm{CFU} / \mathrm{ml}$ was obtained on wood (Figure 2). When the incubation time was extended to 72 hours, biofilm formation on the two surfaces developed much more on glass than the previous hours with a resultant bacterial count of $1.28 \times 10^{9} \mathrm{CFU} / \mathrm{ml}$ while a relatively higher biofilm cells with a count of $7.60 \times 108 \mathrm{CFU} / \mathrm{ml}$ was obtained on wood (Figure 2). The increase in high number of biofilm cells quantified on the surfaces especially on glass varied with the report of Di Bonaventura et al., (2008) that bacteria usually attached to hydrophobic surfaces than hydrophilic, and increased hydrophobicity at high temperatures 
such as $27{ }^{\circ} \mathrm{C}$ employed in this study may enhance the initial adherence of bacteria leading to a higher biofilm density.

\section{Efficacy of Disinfectants at Refrigeration Temperature $\left(10{ }^{\circ} \mathrm{C}\right)$}

The bactericidal effect of the various disinfectants at refrigeration temperatures produced varied results with some viable cells resisting the killing effects of the disinfectants. At refrigeration temperature following exposure to hydrogen peroxide (HP), E. coli biofilm cells developed on glass and wood were completely killed with no surviving cells. After treatment with acetic acid (PAA), the number of $E$. coli viable cells of the biofilm adhered to glass was reduced to $4.10 \times 10^{7}$ less than the positive control $\left(9.00 \times 10^{8} \mathrm{CFU} / \mathrm{ml}\right)$, with a $\log$ reduction (LR) value of 1.35 while the number of viable cells attached to wood was reduced to $3.00 \times 10^{7} \mathrm{CFU} / \mathrm{ml}$ which was also less than the positive control $\left(7.00 \times 10^{8} \mathrm{CFU} / \mathrm{ml}\right)$ with LR value of 1.37 greater than that of glass (Table 1).

When the surfaces were treated with sodium hypochlorite $(\mathrm{SH})$, the bactericidal action of the disinfectant has reduced the number of viable cells on glass to a count of $1.40 \times 10^{8} \mathrm{CFU} / \mathrm{ml}$ with LR value of 0.81 while the number of viable cells of the biofilm formed on wood was reduced to $1.00 \times 10^{8} \mathrm{CFU} / \mathrm{ml}$ with LR value of 0.85 . Compared to the positive control on glass $(9.00$ $\mathrm{x} 10^{8} \mathrm{CFU} / \mathrm{ml}$ ) the action of PAA $+\mathrm{SH}$ has reduced the number of viable cells adhered to glass to count of $1.30 \times 10^{8} \mathrm{CFU} / \mathrm{ml}$ with LR value of 0.84 whilst the action of thesecombinations on wood has reduced the number of viable cells to a count of $3.00 \times 10^{7}$ $\mathrm{CFU} / \mathrm{ml}$ which was also less than the positive control $\left(7.00 \times 10^{8}\right.$ $\mathrm{CFU} / \mathrm{ml}$ ) as illustrated in table 1 . It can be seen that at refrigeration temperature HP was the most effective against the biofilm on the surfaces, followed by PAA, then the mixture of PAA $+\mathrm{SH}$ while HP was the least effective against the biofilm although it has also reduced the viable cells to a greater extend (Table 1).

Although the LR values obtained in this work were not up to 3 , greater number of viable cells of the biofilm developed on the surfaces was reduced. Many reports on disinfectants efficacy have proposed a LR value of 4 or 5 to be consider as effective. Sultan et al.,(2006) reported that in order to prove disinfectant efficiency, there has to be a 5-log reduction (a reduction in the number of microorganisms by 100,000 -fold) in initial cell concentrations. Luppens et al., (2002) reported that a disinfectant that resulted in more than a 4-log reduction in 5 minutes in a biofilm of cell concentration $\left(4 \times 10^{7}\right.$ to $\left.1.3 \times 10^{8} \mathrm{CFU} / \mathrm{cm}^{2}\right)$ should be considered an effective agent on biofilms. Wirtanen et al., (2002) proposed that for a biofilm test only a 3-log reduction was necessary, but Luppens et al., (2002) pointed out that a 3-log reduction is too small for biofilms that can contain cells up to $1.3 \times$ $10^{8} \mathrm{CFU} / \mathrm{cm}^{2}$ (Companac et al., 2002; Sultan et al., 2006).

\section{Efficacy of Disinfectants at Room Temperature $\left(27^{\circ} \mathrm{C}\right)$}

At $27{ }^{\circ} \mathrm{C}$ compared with the positive control on glass $\left(1.60 \times 10^{9} \mathrm{CFU} / \mathrm{ml}\right)$ the bactericidal effect of hydrogen peroxide on glass was not hundred percent effective with remaining surviving bacterial count of $7.00 \times 10^{7} \mathrm{CFU} / \mathrm{ml}$ and $1.36 \mathrm{LR}$ values, while its action on wood has completely killed the biofilm (Table 2). After treatment of the biofilm on glass with PAA, a high number of viable cells resisted the bactericidal with surviving viable count of $1.00 \times 10^{8} \mathrm{CFU} / \mathrm{ml}$ and LR values of 0.20 resulting in higher number of survival fraction (SF) of viable cells than the percentage killed (PK) (Table 2).The effect of PAA on biofilm developed on wood has reduced the viable cells of the biofilm to a count of $8.00 \times 10^{8} \mathrm{CFU} / \mathrm{ml}$ less than the cells on glass and with greater LR value of 1.16 than the LR value obtained on glass (Table 2).

High number of viable cells resisted the killing effect of SH on glass yielding a count of $2.30 \times 10^{8} \mathrm{CFU} / \mathrm{ml}$ with less LR value of 0.84 . The action of $\mathrm{SH}$ on wood has to a greater extend reduced the viable cells of the biofilm to account of $1.80 \times 10^{8}$ $\mathrm{CFU} / \mathrm{ml}$, and with LR values of 0.97 greater than the values obtained on glass (Table 2). Hypochlorite is a very reactive compound and is generally known to be little effective against biofilms (Scher et al., 2005). Increasing the concentration of the disinfectants beyond the recommended user concentration may increase the bactericidal activity, but such concentrations may not be relevant from a practical point of view because of the factors such as corrosion, solubility, health issues and costs (Moretro et al., 2009). A study by Vestby et al., (2010) also concluded that neither hypochlorite nor benzalkonium chloride achieved a $4 \log$ reduction, although when combining the disinfectants usedwith a synthetic furanone, this target was achieved (Corcoran et al., 2014). In contrast and although not similar strain, Wong et al., (2010) found that a range of disinfectants, including benzalkonium chloride and sodium hypochlorite, reduced 3-, 5-,and 7-day Salmonella biofilms by $4 \log$ reduction.

Highest number of cells on glass resisted the killing effect after treatment of the biofilm with PAA $+\mathrm{SH}$ resulting in a count of $2.40 \times 10^{8} \mathrm{CFU} / \mathrm{ml}$ and with less LR values of 0.82 . The effect of the mixture of the disinfectants on wood has reduced the viable cells of the biofilm to a count of $1.50 \times 10^{8} \mathrm{CFU} / \mathrm{ml}$ with LR values of 0.89 relatively greater than the LR values obtained on glass (Table 4). Preliminary data has suggested that covering a dried inoculum with disinfectant without any further mechanical action to improve contact between organisms and disinfectant, will usually result in lower reduction factors than those obtained with suspension test (Van Klingeren et al., 1998). Thus the low LR values/factors obtained in this study may be attributed to not applying these mechanical actions. However, in many instances, the concentration necessary to reduce the cell numbers above the 4 log threshold was also above the concentration recommended by the manufacturer (Wong et al., 2010).

The difference in results may reflect the differences in the method of biofilm formation and in particular the surface area available for biofilm formation. Møretrø et al., (2009) also highlighted the difference in efficacy of disinfectants using different methods of testing, such as the pellicle test, suspension test, and European surface test EN 13697:2001. 
Table 1: Efficacy of Disinfectants against 168 hours Biofilm developed at $10^{\circ} \mathrm{C}$.

\begin{tabular}{|c|c|c|c|c|c|c|}
\hline Disinfectants & Surfaces & Positive control (CFU/ml) & No. of surviving cells (CFU/ml) & LR & $\% \mathrm{SF}$ & $\%$ Killed \\
\hline Hydrogen peroxide & Glass & $9.00 \times 10^{8}$ & (1) & - & 0.00 & 100 \\
\hline (HP) & Wood & $7.10 \times 10^{8}$ & - & - & 0.00 & 100 \\
\hline Para Acetic Acid & Glass & $9.00 \times 10^{8}$ & $4.00 \times 10^{7}$ & 1.35 & 4.44 & 95.56 \\
\hline (PAA) & Wood & $7.10 \times 10^{8}$ & $3.00 \times 10^{7}$ & 1.37 & 4.23 & 95.77 \\
\hline Sodium hypochlorite & Glass & $9.00 \times 10^{8}$ & $1.40 \times 10^{8}$ & 0.81 & 15.56 & 84.44 \\
\hline$(\mathrm{SH})$ & Wood & $7.10 \times 10^{8}$ & $1.00 \times 10^{8}$ & 0.85 & 14.08 & 85.92 \\
\hline \multirow[t]{2}{*}{$\mathrm{PAA}+\mathrm{SH}$} & Glass & $9.00 \times 10^{8}$ & $1.30 \times 10^{8}$ & 0.84 & 14.44 & 85.56 \\
\hline & Wood & $7.10 \times 10^{8}$ & $3.00 \times 10^{7}$ & 1.37 & 4.23 & 95.77 \\
\hline
\end{tabular}

Table 2: Efficacy of Disinfectants against 168 hours Biofilm developed at $27^{\circ} \mathrm{C}$.

\begin{tabular}{|c|c|c|c|c|c|c|}
\hline Disinfectants & Surfaces & Positive control (CFU/ml) & No. of surviving cells (CFU/ml) & LR & $\% \mathrm{SF}$ & $\%$ Killed \\
\hline Hydrogen peroxide & Glass & $1.60 \times 10^{9}$ & $7.00 \times 10^{7}$ & 1.36 & 4.38 & 95.62 \\
\hline$(\mathrm{HP})$ & Wood & $1.17 \times 10^{9}$ & - & - & 0.00 & 100 \\
\hline Para Acetic Acid & Glass & $1.60 \times 10^{9}$ & $1.00 \times 10^{8}$ & 0.20 & 62.50 & 37.50 \\
\hline (PAA) & Wood & $1.17 \times 10^{9}$ & $8.00 \times 10^{7}$ & 1.16 & 6.84 & 93.16 \\
\hline Sodium hypochlorite & Glass & $1.60 \times 10^{9}$ & $2.30 \times 10^{8}$ & 0.81 & 14.38 & 85.62 \\
\hline$(\mathrm{SH})$ & Wood & $1.17 \times 10^{9}$ & $1.80 \times 10^{8}$ & 0.97 & 10.53 & 89.47 \\
\hline $\mathrm{PAA}+\mathrm{SH}$ & Glass & $1.60 \times 10^{9}$ & $2.40 \times 10^{8}$ & 0.82 & 15.00 & 85.00 \\
\hline & Wood & $1.17 \times 10^{9}$ & $1.50 \times 10^{8}$ & 0.89 & 12.85 & 87.15 \\
\hline
\end{tabular}

\section{CONCLUSION}

In conclusion, the results of this work demonstrated that E. coli can develop biofilm on wood with high density in addition to glass. This could be a serious problem in food industries were packaging, storing and transporting of food products were employed using these surfaces. It was also found from this work that $E$. coli biofilm formation increases with increased temperature and time. The bactericidal action of the different disinfectants has proved effective in reducing the biofilm cells at the two temperatures but HP has proven to be a good disinfectant agent than the rest of the tested disinfectants against $E$. coli biofilm at the two temperatures.

However, PAA has also proven to be a good anti biofilm agent than $\mathrm{SH}$ at 10 and $27{ }^{\circ} \mathrm{C}$, while $\mathrm{SH}$ was more effective than $\mathrm{PAA}+\mathrm{SH}$ at $27{ }^{\circ} \mathrm{C}$. The mixture PAA $+\mathrm{SH}$ has not produce a more lethal effect than their individual effect. Thus there is the need to try different combinations of disinfectants to achieve synergistic action in biofilm elimination.

\section{ACKNOWLEDGEMENT}

Our deep appreciation goes to the Faculty of Medicine, University Sultan Zainal Abidin Malaysia for the provision of the research grand to enable us conduct this study. The effort of Professor Nor Din Bin Simbak, Professor Mutallib and Associate Prof Rahama Hassan is also appreciated toward the progress of this research. Lastly we also acknowledged the effort of laboratory technicians MrFaizol and Miss Azlina for the tireless effort and guidance throughout the course of our laboratory experiments.

\section{REFERENCES}

Adetunji VO, Odetokun IA. Assessment of Biofilm in Escherichia coli O157: H7 and Salmonella Strains: Influence of Cultural Conditions. American Journal of Food Technology, 2012; 7(10):582-595.
Araújo P, Lemos M, Mergulhão F, Melo L, Simões M. 2011. Antimicrobial resistance to disinfectants in biofilms. Science against microbial pathogens: communicating current research and technological advances. Formatex, Spain. pp.826-834.

Boyce TG, Swerdlow DL, Griffin PM. Current concepts: Escherichia coli $\mathrm{O} 157: \mathrm{H} 7$ and the hemolytic-uremic syndrome. N Engl J Med, 1995; 333:364-368.

Brooks JD, Flint SH. Biofilms in the food industry: problems and potential solutions. International journal of food science \& technology, 2008; 43(12):2163-2176.

Cabeça TK, Pizzolitto AC, Pizzolitto EL. Assessment of action of disinfectants against Listeria monocytogenes biofilms.Alimentos e NutriçãoAraraquara, 2008; 17(2):121-125.

Campanac C, Pineau L, Payard A, Baziard-Mouysset G, Roques C. Interactions between biocide cationic agents and bacterial biofilms. Antimicrobial agents and chemotherapy, 2002; 46(5):1469-1474.

Cerca N, Maira-Litrán T, Jefferson KK, Grout M, Goldmann DA, Pier GB.Protection against Escherichia coli infection by antibody to the Staphylococcus aureus poly-N-acetylglucosamine surface polysaccharide. Proceedings of the National Academy of Sciences, 2007; 104(18):7528-7533

Chen HD, Frankel G. Enteropathogenic Escherichia coli: unravelling pathogenesis. FEMS microbiology reviews, 2005;29(1):83-98.

Cheng G, Zhang Z, Chen S, Bryers J D, Jiang S. Inhibition of bacterial adhesion and biofilm formation on zwitterionic surfaces Biomaterials, 2007; 28(29):4192-4199.

Chmielewski RAN, Frank JF. Biofilm formation and control in food processing facilities. Comprehensive reviews in food science and food safety, 2003; 2(1):22 32.

Corcoran M, Morris D, De Lappe N, O'connor J, Lalor P, Dockery P, Cormican M. Commonly used disinfectants fail to eradicate Salmonella enterica biofilms from food contact surface materials. Applied and environmental microbiology, 2014; 80(4):1507-1514.

Costerton JW, Lewandowski Z, Caldwell DE, Koter DR, Lappin-Scott HM. Microbial biofilms. Annu. Rev. Microbiol, 1995; 49 711-745.

Costerton JW, Stewart PS, Greenberg EP. Bacterial biofilms: a common cause of persistent infections. Science, 1999; 284: 1318-22.

Di Bonaventura G, Piccolomini R, Paludi D, D'orio V, Vergara A, Conter M, Ianieri A. Influence of temperature on biofilm formation by Listeria monocytogenes on various food-contact surfaces: relationship with motility and cell surface hydrophobicity. Journal of applied microbiology, 2008; 104(6):1552-1561. 
Feng P, Weagant SD 2002. Diarrheagenic Escherichia coli. Bacteriological analytical manual online.

Fletcher M, Loeb GI. Influence of substratum characteristics on the attachment of a marine pseudomonad to solid surfaces. Applied and Environmental Microbiology, 1979; 37(1):67-72.

Giaouris ED, Nychas GJ E. The adherence of Salmonella enteritidis PT4 to stainless steel: The importance of the air-liquid interface and nutrient availability. Food microbiology, 2006; 23(8), 747-752.

Hamilton M. The Log Reduction (LR) Measure of Disinfectant Efficacy (Vol. 7). KSA-SM-2011;07:2011-11.

Heydorn A, Ersbøll BK, Hentzer M, Parsek MR, Givskov M, Molin S. Experimental reproducibility in flow-chamber biofilms. Microbiology, 2000; 146(10):2409-2415

Jesaitis AJ, Franklin MJ, Berglund D, Sasaki M, Lord CI, Bleazard JB, Lewandowski Z. Compromised host defense on Pseudomonas aeruginosa biofilms: characterization of neutrophil and biofilm interactions. The Journal of Immunology, 2003;171(8):4329-4339.

Kaper JB, Nataro JP, Mobley HL. Pathogenic Escherichia coli. Nature Reviews Microbiology, 2004; 2(2):123-140.

Kostaki M, Chorianopoulos N, Braxou E, Nychas GJ, Giaouris E. Differential biofilm formation and chemical disinfection resistance of sessile cells of Listeria monocytogenes strains under monospecies and dual-species (with Salmonella enterica) conditions. Applied and environmental microbiology, 2012;78(8):2586-2595.

Luppens SBI, Reij MW, Heijden RWL, Rambouts FM, Abee T. Development of a standard test to assess the resistance of Staphylococcus aureus biofilm cells to disinfectants. App Environ Microbiol, 2002; 68:4194-4200.

Mahdavi M, Jalali M, Kasra R. Biofilm formation by Salmonella enteritidis on food contact surfaces. J Biol Sci, 2008; 8(2), 502-505.

Merode AE, van der Mei HC, Busscher HJ, Krom BP. Influence of culture heterogeneity in cell surface charge on adhesion and biofilm formation by Enterococcus faecalis. Journal of bacteriology, 2006; 188(7):2421-2426.

Møretrø T, Vestby LK, Nesse LL, Hannevik S, Kotlarz K, Langsrud S. Evaluation of efficiency of disinfectants against Salmonella from the feed industry. J. Appl. Microbiol, 2009; 106:1005-1012.

Oliveira MM MD, Brugnera DF, Alves E, Piccoli RH. Biofilm formation by Listeria monocytogenes on stainless steel surface and biotransfer potential. Brazilian Journal of Microbiology, 2010; 41(1):97106.
Scher K, Romling U, Yaron S. Effect of heat, acidification, and chlorination on Salmonella entericaserovartyphimurium cells in a biofilm formed at the air-liquid interphase. Appl Environ Microbiol, 2005; $71: 1163-1168$.

Shi X, Zhu X. Biofilm formation and food safety in food industries. Trends in Food Science \& Technology, 2009; 20(9):407-413.

Silagyi KS. Biofilm Formation by Escherichia Coli O157 (Vol. 7).2007.ProQuest

Sritharan M, Sritharan V. Emerging problems in the management of infectious diseases: the biofilms. Indian journal of medical microbiology, 2004; 22(3): 140

Stepanović S, Cirković I, Ranin L. Biofilm formation by Salmonella spp. and Listeria monocytogenes on plastic surface. Letters in Applied Microbiology, 2004; 38(5):428-432.

Sultan N, Sipahi AB, Kırca F, Akça G, Laser Ş. Evaluation of Disinfectant Efficacy against Biofilms and Planktonic Cells Of Slime Producing Bacteria and Yeasts. Gazi Medical Journal, 2006; 17(4).

Van Klingeren B, Koller W, Bloomfield SF, Böhm R, Cremieux A, Holah J, Rödger H J. Assessment of the efficacy of disinfectants on surfaces. International biodeterioration \& biodegradation, 1998; 41(3): 289-296.

Vestby LK, Lönn-Stensrud J, Møretrø T, Langsrud S, AamdalScheie A, Benneche T, Nesse LL. A synthetic furanone potentiates the effect of disinfectants on Salmonella in biofilm. J. ApplMicrobiol, 2010; 108:771-778.

Wirtanen G, Salo S. Disinfection in food processing-efficacy testing of disinfectants. Reviews in Environmental Science and Biotechnology, 2003; 2(2-4):293-306.

Wong HS, Townsend KM, Fenwick SG, Maker G, Trengove RD, O'Handley RM. Comparative susceptibility of Salmonella Typhimurium biofilms of different ages to disinfectants. Biofouling, 2010; 26: 859- 856.

\section{How to cite this article:}

Muazu A, Rahman NIA, Abdullahi UF, Aliyu S, Ogidi JA, Umar AF. Assessment of Chemical Disinfectants Efficacy against Escherichia coli Biofilm Developed on Glass and Wood at Refrigeration and Room Temperatures. J App Pharm Sci, 2015; 5 (12): 074-079. 